\title{
Association between anterior open bite and impact on quality of life of preschool children
}

\section{Joana RAMOS-JORGE(a) Thiago MOTTA(b) \\ Leandro Silva MARQUES(a) \\ Saul Martins PAIVA(c) \\ Maria Letícia RAMOS-JORGE(a)}

(a) Universidade Federal dos Vales do Jequitinhonha e Mucuri - UFVJM, School of Dentistry, Department of Pediatric Dentistry and Orthodontics, Diamantina, MG, Brazil.

(b) Private practice, Belo Horizonte, MG, Brazil.

(c) Universidade Federal de Minas Gerais UFMG, School of Dentistry, Department of Pediatric Dentistry and Orthodontics, Belo Horizonte, MG, Brazil.

Declaration of Interests: The authors certify that they have no commercial or associative interest that represents a conflict of interest in connection with the manuscript.

\section{Corresponding Author:}

Joana Ramos-Jorge

E-mail: joanaramosjorge@gmail.com

DOI: 10.1590/1807-3107BOR-2015.vol29.0046

Submitted: Jun 06, 2014

Accepted for publication: Dec 01, 2014

Last revision: Feb 03, 2015

\begin{abstract}
The aim of this study was to evaluate the association between different types of malocclusion and the impact on quality of life among preschoolers and their families. A cross-sectional study was carried out involving 451 children 3-5 years of age. A clinical exam was performed to evaluate the malocclusions according to criteria proposed by Foster and Hamilton. This examination was conducted by a calibrated dentist. Parents/caregivers answered the Early Childhood Oral Health Impact Scale (ECOHIS) for the assessment of Oral Health-Related Quality of Life (OHRQoL) and the questionnaire on socioeconomic and demographic characteristics. Data analysis involved descriptive statistics, chi-square, Mann-Whitney and hierarchically adjusted Poisson regression. The prevalence of malocclusion was $28.4 \%$. The most frequent conditions were posterior crossbite $(20.4 \%)$, anterior open bite (9.5\%) and increased overjet (8.4\%). A significant association was found between anterior open bite and OHRQoL $(p<0.001)$. The adjusted analysis confirmed the association between anterior open bite and a negative impact on quality of life (PR $=2.55$; 95\%CI: 1.87 to 3.47 ; $p<0.001)$. Anterior open bite was associated with a negative impact on the quality of life of preschoolers.
\end{abstract}

Keywords: Malocclusion; Child, Preschool; Quality of Life.

\section{Introduction}

In Brazil, the frequency of malocclusion among preschool children is as high as $69.9 \%$. ${ }^{1}$ However, the prevalence varies according to the parameters used for the diagnosis. Bear in mind that other studies have reported lower rates than this study. ${ }^{2,3,4,5} \mathrm{~A}$ longitudinal study found that children with anterior open bite, increased overjet and posterior crossbite in the primary dentition are at greater risk of exhibiting the same characteristics in the mixed dentition. ${ }^{6} \mathrm{~A}$ clinical trial reported that the diagnosis of malocclusion in the mixed and permanent dentitions may be based on bite characteristics in the primary dentition. ${ }^{7}$ These studies demonstrate the importance of detecting malocclusion in preschool children as a prognostic action allowing early planning of treatment.

However, the early diagnosis of malocclusion is hindered by the low percentage of preschoolers who visit the dentist. ${ }^{8}$ Therefore, the evaluation of parents' perceptions regarding oral health is particularly important in this population. The combination of oral health status - 
evaluated according to normative clinical criteria - and investigation of Oral Health-Related Quality of Life (OHRQoL) constitutes an important tool for clinical decision-making and the establishment of priorities in public oral health policies.

The investigation of OHRQoL among preschoolers is carried out with the assistance of parents, since children younger than 6 years of age may not remember events accurately in a time interval greater than 24 hours $^{9}$ and have limitations regarding the verbalization of emotions and anguish. ${ }^{10}$ The Early Childhood Oral Health Impact Scale (ECOHIS) is a practical questionnaire that can be used in epidemiological surveys ${ }^{11}$ and be administered to parents/caregivers of preschool children. It has been translated and validated in Brazilian Portuguese. ${ }^{12}$

The majority of studies employing the ECOHIS have not found a significant association between malocclusion and impact on quality of life among preschool children. ${ }^{2,3,5,13,14,15}$ However, many studies have considered only the presence/absence of malocclusion in the analysis. Thus, the aim of the present study was to evaluate associations between different types of malocclusion and the impact on the quality of life of preschool children and their families.

\section{Methodology}

A population-based, cross-sectional study was conducted involving preschoolers in Diamantina, a city in the state of Minas Gerais, in southeastern Brazil. A total of 1109 children are enrolled in preschools and distributed among the 20 preschools of the city. ${ }^{16}$ The sample size calculation was performed using a $46.7 \%$ prevalence rate of impact from malocclusion on the quality of life of preschool children, ${ }^{1}$ a $95 \%$ confidence interval and $5 \%$ standard error. The minimum sample was defined as 382 preschool children. A design effect of 1.1 was applied to increase the precision. An additional 84 children were added to compensate for possible losses. The sample distribution was proportional to the total population enrolled in private and public preschools in the city. Accordingly, seven public and two private preschools were selected, totaling 517 enrolled children who fulfilled the inclusion criteria. Of these, 504 children were randomly selected for inclusion in the study.
The inclusion criteria were: age 3-5 years, enrollment at a preschool/daycare center in an urban area in the city of Diamantina, and parents/guardians fluent in Brazilian Portuguese. The exclusion criteria were: currently undergoing orthodontic treatment and systemic disease. Parents/caregivers were asked to answer the Brazilian version of the ECOHIS ${ }^{12}$ and fill out a form addressing sociodemographic information. The ECOHIS was used to assess the impact of malocclusion on quality of life. The clinical oral examination of the children was performed at the preschools by a single dentist. The examiner had previously undergone a calibration exercise, during which interexaminer and intraexaminer Kappa values were greater than 0.8 for all oral conditions evaluated. Both theoretical and practical exercises were performed. After the dentist brushed the child's teeth, he examined the child with a head lamp $\left(\mathrm{PETZL}^{\circledR}\right.$, Tikka XP, Crolles, France), mouth mirrors (PRISMA, Sao Paulo, Brazil), and both WHO and periodontal probes (Golgran Ind. e Com. Ltda., Sao Paulo, Brazil).

Malocclusion was recorded in the presence of increased overjet, anterior open bite, posterior crossbite and anterior crossbite. The measurement (in millimeters) was performed with the teeth in centric occlusion and the periodontal probe positioned parallel to the occlusal plane. Increased overjet was recorded when the distance was $>3 \mathrm{~mm}$. Anterior open bite was recorded in the absence of a vertical overlap of the incisors in the occlusal position. Posterior crossbite was recorded when upper primary molars were occluded in a lingual relationship to the lower primary molars. Anterior crossbite was recorded when the lower incisors were observed in front of the upper incisors. These diagnostic criteria of malocclusion were defined by Foster and Hamilton. ${ }^{17}$

Dental caries and traumatic dental injury (TDI) were evaluated as possible confounding variables. The clinical diagnosis of dental caries was assessed based on WHO criteria. ${ }^{18}$ TDI was performed using the criteria proposed by Andreasen and Lovschall. ${ }^{19}$ The pilot study showed no need for modification of the methodology.

Statistical analysis was performed using the SPSS 20.0 program for Windows (SPSS Inc., Chicago, USA). The Kolmogorov-Smirnov test was used to evaluate the 
normality of quantitative variable distributions. Based on the results, the nonparametric Mann-Whitney test was employed. The dependent variable was impact from oral conditions on quality of life (total ECOHIS score).

The independent variables were grouped into a hierarchy of categories ranging from distal to proximal determinants. ${ }^{20,21}$ Poisson regression analysis with robust variance was performed for each level, to associate the overall mean ECOHIS score with each clinical oral condition, sociodemographic factor and characteristic of the child. This analysis was performed to exclude variables with a $p$-value of $<0.20$. Only explanatory variables with a $p$-value of $<0.05$ after adjustment for variables on the same or prior levels of determinants were selected for the final models. In these analyses, the outcome was employed as a count total.

This study received approval from the Human Research Ethics Committee of the Universidade Federal de Minas Gerais (Belo Horizonte, Brazil) (CAAE: 09066012.3.0000.5149). All parents/guardians received information regarding the objectives of the study, and signed a statement of informed consent.

\section{Results}

A total of 499 preschool children were initially enrolled in the present investigation, 451 (90.4\%) of whom participated until the end of the study. The main reason for losses was that parents/caregivers failed to fill out the questionnaire. Mean age (standard deviation) of the preschool children was 4.25 (0.83) years; $53.9 \%$ were female. The prevalence of malocclusion was $28.4 \%$. The most frequent conditions were posterior crossbite $(20.4 \%)$, anterior open bite $(9.5 \%)$ and accentuated overjet (8.4\%). Dental caries and TDI were present in $34.8 \%$ and $17.5 \%$ of the sample, respectively.

The majority of parents/caregivers reported no impact on quality of life (52.8\%). Parents reported more impacts related to the child (42.8\%) than the family (29.3\%). Table 1 displays the mean ECOHIS scores (total and domain), according to the different oral clinical conditions. Significant associations were found between impact on the child's and family's quality of life and both anterior open bite and dental caries.
The univariate analysis considering the characteristics of the preschool children, as well as demographic factors, revealed that impact on quality of life was associated with the age of the child and with the mother working outside the home. Regarding clinical oral conditions, anterior open bite and dental caries were associated with a greater impact prevalence rate (Table 2).

In the final multivariate model (Table 3), anterior open bite (PR: 2.55; 95\%CI: 1.87 to 3.47; $p<0.001$ ), dental caries (PR: 6.87; 95\%CI: 5.04 to 9.36; $p<0.001$ ) and lower level of mother's schooling were associated with a negative impact on quality of life.

\section{Discussion}

The prevalence rate of malocclusion in the present study $(28.4 \%)$ was lower than the rate reported in a previous Brazilian investigation (46.7\%). ${ }^{5}$ However, the cutoff point for increased overjet was $2 \mathrm{~mm}$ in the study cited and $>3 \mathrm{~mm}$ in the present investigation. Overjet up to $3 \mathrm{~mm}$ in the primary dentition is not considered a risk factor for malocclusion in mixed dentition. ${ }^{6}$ However, previous studies have found an association between overjet greater than $3 \mathrm{~mm}$ and TDI. ${ }^{22,23}$ This reinforces the importance of evaluating increased overjet, considering a cutoff point of $>3 \mathrm{~mm}$. Another Brazilian study reports a $69.9 \%$ prevalence rate of malocclusion in the anterior region, using a cutoff point of $>2 \mathrm{~mm}$ for determining increased overjet. ${ }^{1}$ Since young children may exhibit nonnutritive sucking habits, ${ }^{24}$ it is important to stress than the mean age of the children in the present study was $4.25(\mathrm{SD}=0.83)$ years, whereas mean age in the study by Kramer et al. ${ }^{1}$ was $3.5(\mathrm{SD}=1.0)$ years. This result may show that the damage caused by nonnutritive sucking habits can be corrected spontaneously after cessation of these habits. ${ }^{25}$

The present investigation evaluated the impact of different types of malocclusion on quality of life among preschool children, in contrast to many studies ${ }^{3,5,13}$ that confirm this relationship based solely on the presence/absence of this oral disorder. Parents of children with anterior open bite reported negative impacts on most of the ECOHIS domains, with the exception of "symptoms." Considering the mean total ECOHIS score, only anterior open bite and dental caries were significantly associated with impact on quality of life. 
Table 1. Mean scores on ECOHIS domains according to different oral clinical conditions.

\begin{tabular}{|c|c|c|c|c|c|c|c|c|}
\hline Oral clinical conditions & n (\%) & SD & FD & PD & SSD & PDD & FFD & $\begin{array}{c}\text { Mean ECOHIS } \\
\text { score }\end{array}$ \\
\hline \multicolumn{9}{|l|}{ Anterior open bite } \\
\hline Absent & $408(90.5)$ & $0.74(1.20)$ & $1.02(2.21)$ & $0.64(1.41)$ & $0.53(1.49)$ & $1.02(2.06)$ & $0.31(1.07)$ & $4.15(7.50)$ \\
\hline Present & $43(9.5)$ & $1.12(1.40)$ & $3.77(3.27)$ & $2.26(2.90)$ & $1.67(2.36)$ & $3.12(2.96)$ & $1.56(1.94)$ & 11.65 (10.35) \\
\hline$p$-value & & 0.079 & $<0.001$ & $<0.001$ & $<0.001$ & $<0.001$ & $<0.001$ & $<0.001$ \\
\hline \multicolumn{9}{|l|}{ Increased overjet } \\
\hline Absent & $413(91.6)$ & $0.80(1.24)$ & $1.24(2.42)$ & $0.77(1.61)$ & $0.63(1.61)$ & $1.22(2.23)$ & $0.36(1.15)$ & $4.77(8.04)$ \\
\hline Present & $38(8.4)$ & $0.53(1.01)$ & $1.74(2.89)$ & $1.16(2.23)$ & $0.82(1.74)$ & $1.21(2.44)$ & $1.21(1.76)$ & $5.89(8.85)$ \\
\hline$p$-value & & 0.186 & 0.313 & 0.272 & 0.414 & 0.900 & $<0.001$ & 0.070 \\
\hline \multicolumn{9}{|l|}{ Posterior crossbite } \\
\hline Absent & $359(79.6)$ & $0.83(1.23)$ & $1.18(2.32)$ & $0.72(1.47)$ & $0.60(1.56)$ & $1.16(2.15)$ & $0.34(1.14)$ & $4.69(7.72)$ \\
\hline Present & $92(20.4)$ & $0.59(1.17)$ & $1.67(2.93)$ & $1.09(2.29)$ & $0.80(1.84)$ & $1.46(2.58)$ & $0.77(1.51)$ & $5.59(9.46)$ \\
\hline$p$-value & & 0.040 & 0.326 & 0.555 & 0.594 & 0.537 & 0.002 & 0.979 \\
\hline \multicolumn{9}{|l|}{ Anterior crossbite } \\
\hline Absent & $447(99.1)$ & $0.78(1.22)$ & $1.30(2.47)$ & $0.79(1.68)$ & $0.65(1.64)$ & $1.21(2.24)$ & $0.43(1.24)$ & $4.87(8.14)$ \\
\hline Present & $4(0.9)$ & $0.80(1.09)$ & $0.20(0.45)$ & $1.80(0.48)$ & $0.10(0.25)$ & $2.00(2.83)$ & $0.40(0.89)$ & $5.20(1.35)$ \\
\hline$p$-value & & 0.848 & 0.517 & $<0.001$ & 0.326 & 0.455 & 0.786 & 0.072 \\
\hline \multicolumn{9}{|l|}{ Dental caries } \\
\hline Absent & $294(65.2)$ & $0.17(0.54)$ & $0.43(1.20)$ & $0.19(0.69)$ & $0.08(0.45)$ & $0.36(1.20)$ & $0.22(0.82)$ & $1.43(3.30)$ \\
\hline Present & $157(34.8)$ & $1.92(1.32)$ & 2.89 (3.29) & $1.94(2.28)$ & $1.70(2.35)$ & $2.83(2.80)$ & $0.82(1.70)$ & $11.21(10.24)$ \\
\hline p-value & & $<0.001$ & $<0.001$ & $<0.001$ & $<0.001$ & $<0.001$ & $<0.001$ & $<0.001$ \\
\hline \multicolumn{9}{|l|}{ Traumatic dental injury } \\
\hline Absent & $372(82.5)$ & $0.77(1.20)$ & $1.37(2.55)$ & $0.81(1.70)$ & $0.67(1.71)$ & $1.31(2.33)$ & $0.41(1.24)$ & $5.03(8.41)$ \\
\hline Present & $79(17.5)$ & $0.80(1.33)$ & $0.90(1.96)$ & $0.72(1.58)$ & $0.51(1.12)$ & $0.78(1.77)$ & $0.51(1.21)$ & $4.13(6.48)$ \\
\hline$p$-value & & 0.842 & 0.143 & 0.696 & 0.707 & 0.091 & 0.440 & 0.728 \\
\hline
\end{tabular}

Values expressed as mean (standard deviation); Mann-Whitney test.

$\mathrm{SD}=$ symptoms domain (score ranges from 0 to 5 ); $F D=$ function domain (score ranges from 0 to 0 to 16 ); PD = psychological domain (score ranges from 0 to 8 ); SSD = self-image/social interaction domain (score ranges from 0 to 8); PDD = parent distress domain (score ranges from 0 to 8 ); FFD = family function domain (score ranges from 0 to 8 )

Because other risk factors may cause interference, it is important to consider possible correlations with confounding factors. ${ }^{26,27}$ In the present study, caries and TDI were investigated as potential confounding variables. Moreover, Locker ${ }^{28}$ suggests that the relationship between oral health and quality of life outcomes is mediated by personal and environmental variables. This demonstrates the importance of evaluating demographic factors, as was done in the present study.

Regarding type of malocclusion, the univariate analysis showed that anterior open bite was significantly associated with a negative impact on quality of life; this was confirmed in the final Poisson regression model. This finding is noteworthy, since the same association occurred with dental caries, which is an important confounding variable. A study with preschoolers in the city of Canoas, Brazil, also found an association between malocclusion and quality of life. ${ }^{1}$

It is important for parents/caregivers to perceive the functional limitations associated with anterior open bite, such as difficulty eating and pronouncing words, since this malocclusion may be carried over into the mixed dentition. ${ }^{6}$ Moreover, the satisfaction/dissatisfaction expressed by parents with regard to their child's oral health could also be attributed to this association. ${ }^{29}$ Perceptions such as these may contribute to the decision to seek treatment. The fact that anterior open bite, dental caries and mother's schooling remained in the final model is in agreement with data described in a study conducted in the city of Santa Maria, in southern Brazil. ${ }^{30}$ 
Table 2. Univariate analysis of associations among oral clinical conditions, characteristics of children, and both sociodemographic and economic factors in relation to overall ECOHIS.

\begin{tabular}{|c|c|c|c|}
\hline Covariates & n (\%) & PR & p-value \\
\hline \multicolumn{4}{|l|}{ Characteristics of child } \\
\hline \multicolumn{4}{|l|}{ Gender } \\
\hline Female & $243(53.9)$ & 1 & \\
\hline Male & $208(46.1)$ & $0.99(0.77-1.27)$ & 0.973 \\
\hline \multicolumn{4}{|l|}{ Age } \\
\hline 3 years & $114(25.2)$ & 1 & \\
\hline 4 years & $109(24.2)$ & $1.77(1.12-2.79)$ & 0.004 \\
\hline 5 years & $228(50.6)$ & $1.79(1.20-2.66)$ & 0.013 \\
\hline \multicolumn{4}{|c|}{ Sociodemographic and economic factors - level 1} \\
\hline \multicolumn{4}{|l|}{ Mother's schooling } \\
\hline$>11$ years & $39(8.6)$ & 1 & \\
\hline$>8$ to 11 years & $216(47.9)$ & $7.16(2.62-19.60)$ & $<0.001$ \\
\hline$\leq 8$ years & $196(43.5)$ & $7.83(2.73-22.45)$ & $<0.001$ \\
\hline \multicolumn{4}{|l|}{ Mother works outside the home } \\
\hline Yes & $329(72.9)$ & 1 & \\
\hline No & $122(27.1)$ & $0.51(0.37-0.69)$ & $<0.001$ \\
\hline \multicolumn{4}{|l|}{ Household income } \\
\hline$>3$ times the minimum wage & $80(17.7)$ & 1 & \\
\hline 3 times the minimum wage & $138(30.6)$ & $0.81(0.49-1.33)$ & 0.406 \\
\hline$\leq 2$ times the minimum wage & $233(51.7)$ & $0.85(0.52-1.38)$ & 0.513 \\
\hline \multicolumn{4}{|l|}{ Type of school (child) } \\
\hline Private & $35(7.8)$ & 1 & \\
\hline Public & $416(92.2)$ & $0.529(0.20-1.37)$ & 0.192 \\
\hline \multicolumn{4}{|l|}{ Oral clinical conditions - level 2} \\
\hline \multicolumn{4}{|l|}{ Anterior open bite } \\
\hline Absent & $408(90.5)$ & 1 & \\
\hline Present & $43(9.5)$ & $3.75(2.26-6.24)$ & $<0.001$ \\
\hline \multicolumn{4}{|l|}{ Increased overjet } \\
\hline Absent & $413(91.6)$ & 1 & \\
\hline Present & $38(8.4)$ & $1.54(0.98-2.41)$ & 0.058 \\
\hline \multicolumn{4}{|l|}{ Posterior crossbite } \\
\hline Absent & $359(79.6)$ & 1 & \\
\hline Present & $92(20.4)$ & $0.65(0.41-1.03)$ & 0.067 \\
\hline \multicolumn{4}{|l|}{ Anterior crossbite } \\
\hline Absent & $447(99.1)$ & 1 & \\
\hline Present & $4(0.9)$ & $1.12(0.57-2.22)$ & 0.738 \\
\hline \multicolumn{4}{|l|}{ Dental caries } \\
\hline Absent & $294(65.2)$ & 1 & \\
\hline Present & $157(34.8)$ & $8.54(6.42-11.36)$ & $<0.001$ \\
\hline \multicolumn{4}{|l|}{ Traumatic dental injury } \\
\hline Absent & $372(82.5)$ & 1 & \\
\hline Present & $79(17.5)$ & 1.18 (0.83-1.67) & 0.350 \\
\hline
\end{tabular}

PR calculated by the Wald chi-square test; the minimum wage is approximately US $\$ 305.00$. 
Table 3. Final Poisson regression model for covariates associated with overall ECOHIS.

\begin{tabular}{|c|c|c|}
\hline Covariates & Robust PR & $p$-value \\
\hline \multicolumn{3}{|l|}{ Characteristics of child } \\
\hline \multicolumn{3}{|l|}{ Gender } \\
\hline Female & 1 & \\
\hline Male & $1.01(0.74-1.37)$ & 0.933 \\
\hline \multicolumn{3}{|l|}{ Age } \\
\hline 3 years & 1 & \\
\hline 4 years & $2.56(1.46-4.50)$ & 0.001 \\
\hline 5 years & $3.19(2.04-4.93)$ & $<0.001$ \\
\hline \multicolumn{3}{|c|}{ Socio-demographic and economic factors - level 1} \\
\hline \multicolumn{3}{|c|}{ Mother's schooling } \\
\hline$>11$ years & 1 & \\
\hline$>8$ to 11 years & $6.10(2.87-12.95)$ & $<0.001$ \\
\hline$\leq 8$ years & $7.68(3.61-16.33)$ & $<0.001$ \\
\hline \multicolumn{3}{|l|}{ Age } \\
\hline 3 years & 1 & \\
\hline 4 years & $2.81(1.64-4.80)$ & $<0.001$ \\
\hline 5 years & $3.18(2.02-5.00)$ & $<0.001$ \\
\hline \multicolumn{3}{|c|}{ Oral clinical conditions - level 2} \\
\hline \multicolumn{3}{|c|}{ Anterior open bite } \\
\hline Absent & 1 & \\
\hline Present & $2.55(1.87-3.47)$ & $<0.001$ \\
\hline \multicolumn{3}{|l|}{ Dental caries } \\
\hline Absent & 1 & \\
\hline Present & $6.87(5.04-9.36)$ & $<0.001$ \\
\hline \multicolumn{3}{|l|}{ Age } \\
\hline 3 years & 1 & \\
\hline 4 years & $1.61(1.02-2.54)$ & 0.058 \\
\hline 5 years & $1.59(1.05-2.42)$ & \\
\hline \multicolumn{3}{|l|}{ Mother's schooling } \\
\hline$>11$ years & 1 & \\
\hline$>8$ to 11 years & $3.53(1.84-6.76)$ & $<0.001$ \\
\hline$\leq 8$ years & $3.23(1.66-6.25)$ & 0.001 \\
\hline
\end{tabular}

PR calculated by Wald chi-square test; model adjusted for significant variables in the final model of previous levels.

The results of this research are not in agreement with other recent Brazilian studies. ${ }^{2,15}$ One study ${ }^{15}$ did not use a quantitative dependent variable. The authors of this paper ${ }^{15}$ used the response "occasionally" as the cutoff point for determining the prevalence of a negative impact. Abanto et al. ${ }^{2}$ assessed children 1-4 years of age. In the study performed by Sousa et al., ${ }^{15}$ $78 \%$ of the sample consisted of children 3 and 4 years of age, whereas $22 \%$ were 5 years of age. In the present study, $50.6 \%$ of the sample consisted of children 5 years of age. Since parents can understand the limitations of older children more easily, the sampling process may explain the difference in the results.

The present findings suggest that quality of life measures provide important information for clinical decision-making regarding the treatment of malocclusion. However, the present investigation has the limitation of being a cross-sectional and epidemiologic study. Furthermore, information and selection biases may have occurred.

\section{Conclusion}

Anterior open bite was associated with a negative impact on quality of life among preschool children and their families.

\section{Acknowledgments}

This study was supported by FAPEMIG - Fundação de Amparo à Pesquisa do Estado de Minas Gerais, a Brazilian funding agency (PMPD-BPD-00451-13). 


\section{References}

1. Kramer PF, Feldens CA, Ferreira SH, Bervian J, Rodrigues PH, Peres MA. Exploring the impact of oral diseases and disorders on quality of life of preschool children. Community Dent Oral Epidemiol. 2013 Aug;41(4):327-35.

2. Abanto J, TelloG, Bonini GC, Oliveira LB, Murakami C, Bönecker M. Impact of traumatic dental injuries and malocclusions on quality of life of preschool children: a population-based study. Int J Paediatr Dent. 2015 Jan;25(1):18-28.

3. Aldrigui JM, Abanto J, Carvalho TS, Mendes FM, Wanderley MT, Bönecker M, et al. Impact of traumatic dental injuries and malocclusions on quality of life of young children. Health Qual Life Outcomes. 2011 Sep 24;9:78.

4. Carvalho AC, Paiva SM, Scarpelli AC, Viegas CM, Ferreira FM, Pordeus IA. Prevalence of malocclusion in primary dentition in a population-based sample of Brazilian preschool children. Eur J Paediatr Dent. 2011 Jun;12(2):107-11.

5. Scarpelli AC, Paiva SM, Viegas CM, Carvalho AC, Ferreira FM, Pordeus IA. Oral health-related quality of life among Brazilian preschool children. Community Dent Oral Epidemiol. 2013Aug;41(4):336-44.

6. Góis EG, Vale MP, Paiva SM, Abreu MH, Serra-Negra JM, Pordeus IA. Incidence of malocclusion between primary and mixed dentitions among Brazilian children. A 5-year longitudinal study. Angle Orthod. 2012 May;82(3):495-500.

7. Keski-Nisula K, Keski-Nisula L, Mäkelä P, Mäki-Torkko T, Varrela J. Dentofacial features of children with distal occlusions, large overjets, and deepbites in the early mixed dentition. Am J Orthod Dentofacial Orthop. 2006 Sep;130(3):292-9.

8. Kramer PF, Ardenghi TM, Ferreira S, Fischer LA, Cardoso L, Feldens CA. Use of dental services by preschool children in Canela, Rio Grande do Sul State, Brazil. Cad Saude Publica. 2008 Jan;24(1):150-6.

9. Rebok G, Riley A, Forrest C, Starfield B, Green B, Robertson J, et al. Elementary school-aged children's reports of their health: a cognitive interviewing study. Qual Life Res. 2001;10(1):59-70.

10. Talekar BS, Rozier RG, Slade GD, Ennett ST. Parental perceptions of their preschool-aged children's oral health. J Am Dent Assoc. 2005 Mar;136(3):364-72.

11. Pahel BT, Rozier RG, Slade GD. Parental perceptions of children's oral health: the Early Childhood Oral Health Impact Scale (ECOHIS). Health Qual Life Outcomes. 2007 Jan 30;5:6.

12. Martins-Júnior PA, Ramos-Jorge J, Paiva SM, Marques LS, Ramos-Jorge ML. Validations of the Brazilian version of the Early Childhood Oral Health Impact Scale (ECOHIS). Cad Saude Publica. 2012 Feb;28(2):367-74.

13. Carvalho TS, Abanto J, Mendes FM, Raggio DP, Bönecker M. Association between parental guilt and oral health problems in preschool children. Braz Oral Res. 2012 Nov-Dec;26(6):557-63.

14. Carvalho AC, Paiva SM, Viegas CM, Scarpelli AC, Ferreira FM, Pordeus IA. Impact of malocclusion on oral healthrelated quality of life among Brazilian preschool children: a population-based study. Braz Dent J. 2013 Nov-Dec;24(6):655-61.
15. Sousa RV, Clementino MA, Gomes MC, Martins CC, GranvilleGarcia AF, Paiva SM. Malocclusion and quality of life in Brazilian preschoolers. Eur J Oral Sci. 2014 Jun;122(3):223-9.

16. Instituto Brasileiro de Geografia e Estatística. Rio de Janeiro (RJ): IBGE; Estimativas populacionais para os municípios brasileiros (Brasil); 2013 [cited 2014 May 07]. Available from: http://www.ibge.gov.br/cidadesat/painel/painel.php?codmun $=312160 \#$.

17. Foster TD, Hamilton MC. Occlusion in the primary dentition: study of children at 2 and one-half to 3 years of age. Br Dent J. 1969 Jan;126(2):76-9.

18. World Health Organization. Oral health surveys: basic methods, 4th ed. Geneve: World Health Organization; 1997. 73 p.

19. Andreasen JO, Lovschall H. Response of oral tissues to trauma. In: Andreasen JO, Andreasen FM, Andersson L. Textbook and color atlas of traumatic injuries to the teeth. 4th ed. Oxford: Wiley-Blackwell; 2007. p. 62-113.

20. Victora CG, Huttly SR, Fuchs SC, Olinto MT. The role of conceptual frameworks in epidemiological analysis: a hierarchical approach. Int J Epidemiol. 1997 Feb;26(1):224-7.

21. Peres MA, Latorre MRO, Sheiham A, Peres KG, Barros FC, Hernandez PG, et al. Social and biological early life influences on severity of dental caries in children aged 6 years. Community Dent Oral Epidemiol. 2005 Feb;33(1):53-63.

22. Piovesan C, Guedes RS, Casagrande L, Ardenghi TM. Socioeconomic and clinical factors associated with traumatic dental injuries in Brazilian preschool children. Braz Oral Res. 2012 Sep-Oct;26(5):464-70.

23. Goettems ML, Azevedo MS, Correa MB, Costa CT, Wendt FP, Schuch HS, et al. Dental trauma occurrence and occlusal characteristics in Brazilian preschool children. Pediatr Dent. 2012 Mar-Apr;34(2):104-7.

24. Vasconcelos FM, Massoni AC, Heimer MV, Ferreira AM, Katz $\mathrm{CR}$, Rosenblatt A. Non-nutritive sucking habits, anterior open bite and associated factors in Brazilian children aged 30-59 months. Braz Dent J. 2011;22(2):140-5.

25. Mistry P, Moles DR, O'Neill J, Noar J. The occlusal effects of digit sucking habits amongst school children in Northamptonshire (UK). J Orthod. 2010 Jun;37(2):87-92.

26. Newton JT, Bower EJ. The social determinants of oral health: new approaches to conceptualizing and researching complex causal networks. Community Dent Oral Epidemiol. 2005 Feb;33(1):25-34.

27. Kraemer HC. Epidemiological methods: about time. Int J Environ Res Public Health. 2010 Jan;7(1):29-45.

28. Locker D. Disparities in oral health-related quality of life in a population of Canadian children. Community Dent Oral Epidemiol. 2007 Oct;35(5):348-56.

29. Reisine $S$. An overview of self-reported outcome assessment in dental research. J Dent Educ. 1996 Jun;60(6):488-93.

30. Piovesan C, Marquezan M, Kramer PF, Bönecker M, Ardenghi TM. Socioeconomic and clinical factors associated with caregivers' perceptions of children's oral health in Brazil. Community Dent Oral Epidemiol. 2011 Jun;39(3):260-7. 